\title{
Scurt istoric al amenajării pădurilor din România*
}

\section{G. Duduman}

Duduman G., 2019. Short history of forest management planning in Romania. Bucov. For. 19(2): 139-158

Abstract. This paper is a literature review, aiming to present a short history of forest management planning (FMP) in Romania. The first part is focused on the development of FMP worldwide. The second part describes the occurrence of FMP in Romania, being divided into four different phases, according to the main historical changes that influenced the evolution of forestry and FMP: before 1918, 19181947, 1947-1989 and after 1989. Before 1918, the Romanian FMP system was mainly based on elements from French and German forestry. After the Great Union of 1918, the first concerns arose for the creation of a unitary FMP system but, with some adaptation to local conditions, it was mainly based on the FMP system applied before 1918. Only 39\% of Romanian forests were managed based on a forest management plan in 1947. The apogee of FMP development in Romania occurred between 1947 and 1989: after forest nationalization in 1948, a huge effort was allocated for the FMP of all Romanian forests, according to a new and unitary national FMP system. Thus, till 1956, there were produced forest management plans for all Romanian forests. This system was periodically updated and improved and a lot of research was performed in this field between 1947 and 1989. After 1989, the FMP system was adapted according to the ownership changes that occurred in the new political context. Other main changes refer to the complete computerized processing of all data collected within the FMP activity and, mainly after 2010, the use of GIS for producing the maps attached to each forest management plan. Keywords: history of forest management planning, Romanian forest management planning, methods of forest management planning, Romanian forestry.

Authors. Gabriel Duduman (gduduman@usv.ro), Ștefan cel Mare University of Suceava, Faculty of Forestry, 13 Universității, 720229 Suceava, Romania

Manuscript received December 23, 2019; revised December 27, 2019; accepted December 30, 2019; online first December 31, 2019.

\section{Apariția amenajării pădurilor}

Apariţia și dezvoltarea agriculturii și a creșterii animalelor acum circa 10000 de ani au constituit principala cauză a marilor transformări ecologice realizate de om după descoperirea focului (Williams 2006). Defrișarea pădurilor pentru schimbarea folosinței terenului nu avea nimic în comun - la acele vremuri și mult timp după aceea - cu ideea de planificare a modului

\footnotetext{
* Material publicat parțial în lucrarea: Duduman G., Drăgoi M., 2019. Amenajarea pădurilor - Vol.1: Organizare spațio-temporală. Editura Universității Ștefan cel Mare Suceava, X+209 p.
} 
de recoltare a lemnului. Preocupările pentru reglementarea acestei activități au apărut odată cu penuria de resurse forestiere, fie ca urmare a diminuării semnificative a suprafeței pădurilor prin schimbarea folosinței, fie datorită utilizării iraționale, care a dus la modificarea condițiilor de vegetație peste pragurile critice care permiteau refacerea naturală a pădurilor.

Exemple concludente în acest sens constituie marile centre culturale de odinioară ce erau înconjurate de păduri întinse, iar astăzi se găsesc în zone deșertice sau improprii creșterii speciilor lemnoase altădată prezente: Egipt, Palestina, Siria, Turcia, Grecia, Italia, Spania, stepele Rusiei de sud, Asia centrală, America de Nord etc (Guguianu 1908). Pădurile au plătit astfel o parte însemnată din costul civilizării societății umane.

Primele măsuri de gospodărire a pădurilor ${ }^{1}$ în Europa datează din vremea romanilor (figura 1). Domeniile romane cuprindeau suprafețe cu păduri situate la marginea vetrelor de sat: unele erau utilizate pentru pășunat și pentru lemn de construcții, iar altele erau gospodărite în regim de crâng și recoltate la vârste mici, pentru satisfacerea nevoilor de lemn de foc (Doussot 1989). Rolul pădurilor în protecția solului este menționat încă din antichitate prin scrierile lui Pliniu cel Bătrân care arată că „după distrugerea pădurilor s-au format torenți primejdioși pe versanți” (Giurgiu 1988). De asemenea, utilizarea resurselor forestiere are o istorie însemnată în China, existând informații în acest sens din timpul dinastiilor Chow (1122 î.Hr. - 255 î.Hr.) și Han (208 î.Hr. - 220)2.

În perioada marilor migrații și în epoca feudală, suprafețe întinse de păduri din Europa au fost defrișate pentru mărirea suprafețelor agricole, pentru utilizarea lemnului ca material de construcții (terestre și navale), sau ca sursă de consolidare a puterii politice a proprietarilor de păduri (Gaudin 1996).

În Europa, exceptând regiunile germanice $^{3}$ în care au existat preocupări sistematice

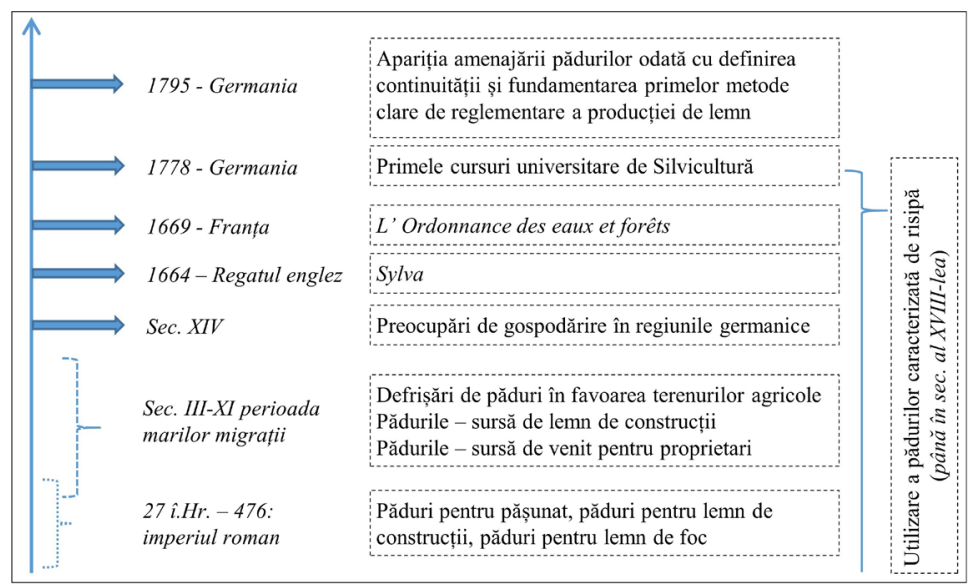

Figura 1 Utilizarea resurselor lemnoase în Europa până la apariția amenajării pădurilor The use of forest resources in Europe before the onset of forest management planning

\footnotetext{
${ }^{1}$ Se disting doi termeni diferiți: gospodărire și utilizare a pădurilor. Cu privire la utilizare (în ideea schimbării folosinței), există mărturii că explozia demografică din Neolitic (5000-2500 1̂.e.n.) a condus la primele defrișări de păduri (Gaudin 1996), însă aceste defrișări nu aveau nimic în comun cu intenția de gospodărire a pădurilor.

${ }^{2} \mathrm{http}: / /$ www.fao.org/3/x5347e/x5347e04.htm\#TopOfPage

${ }^{3}$ Spre exemplu, în Bavaria, primele amenajamente simpliste datează din 1579 și conțineau o descriere sumară a pădurii. În anul 1613 au fost emise aici niște instrucțiuni generale de descriere a pădurilor, fiind definită și noțiunea de revoluție (ciclu de producție). Au urmat instrucțiunile din 1752 și 1788, iar după 1790 au început adevăratele lucrări de amenajare a pădurilor, conduse de către Mathias Schilcher, considerat în Bavaria drept părintele amenajamentului (Backmund 1935).
} 
de gospodărire a pădurilor încă din secolul al XIV-lea (Buttinger 2013), formele de utilizare a resurselor forestiere au condus la risipă și nu aveau nimic în comun cu planificarea.

Abia începând cu a doua jumătate a secolului al XVII-lea au apărut încercări de determinare a consecințelor intervențiilor antropice neplanificate, distructive asupra ecosistemelor forestiere, realizate strict pe raţionamente economice. Documentele considerate în literatură (Westoby 1989) drept puncte de pionierat în acest sens sunt: ,Sylva, or a Discourse of Forest Trees and the Propagation of Timber in His Majesties Dominions" ", publicat în 1664 de scriitorul englez John Evelyn (1620-1706); respectiv „L' Ordonnance de Louis XIV sur le fait des eaux et forêts" ", elaborată în 1669 de Jean-Baptiste Colbert (1619-1683), ministrul de finanțe din timpul regelui Ludovic al XIVlea. Ambele lucrări au constituit adevărate reforme pentru gospodărirea pădurilor, autorii militând pentru împădurirea terenurilor dezgolite și promovând ideea de ,,bon usage de la nature”, preluată ulterior în numeroase țări ale Europei.

La sfârşitul secolului XVIII au apărut în Germania primele cursuri universitare de Silvicultură (1778), respectiv primele școli superioare de silvicultură (începând cu anul 1785), iar până în anul 1850 au fost înființate școli de silvicultură în Rusia, Ungaria, Austria, Suedia, Franța, Spania și Italia. Astfel, momentul apariției amenajării pădurilor ca știință silvică este marcat de publicarea de către silvicultorul german Georg Ludwig Hartig, în anul 1795, a lucrării „,Anweisung zur Taxation der Forste, oder zur Bestimmung des Holzer-Trags der Walder"'. Autorul sintetizează în această lucrare informații importante despre tehnici silvice cunoscute la acea dată și promovează ideea de planificare a consumului de lemn în acord cu capacitatea de producție a pădurilor (Hartig 1795). Apariţia amenajării pădurilor coincide astfel cu o nouă etapă din evoluția societății umane, caracterizată prin creșterea presiunii antropice asupra pădurilor ca urmare a concentrării forței de muncă în zonele urbane şi prin trecerea de la producția manufacturieră la producția de masă, ce presupunea consumul unor cantități imense de lemn ca resursă energetică (Drăgoi 2004).

După 1795, știința amenajării pădurilor s-a dezvoltat continuu, au fost concepute şi perfecționate numeroase metode şi tehnici specifice planificării modului de valorificare a resurselor forestiere, iar în momentul de față reprezintă o activitate obligatorie la nivel global pentru gospodărirea responsabilă a pădurilor și satisfacerea nevoilor crescânde de lemn şi de servicii ecoprotective ale societăţii umane.

\section{Amenajarea pădurilor în România}

\section{Până în 1918}

În România pădurile au constituit de-a lungul timpului loc de adăpost, de refugiu, de procurare a hranei și sursă de lemn de construcții și foc. Cele mai vechi documente istorice care fac trimitere la preocupări primare de gospodărire a pădurilor se referă la existența braniștilor?: încă din 1181 în Transilvania (între Someș și Tisa), în secolul XIII ${ }^{8}$ în Moldova, sau din vremea lui Mircea cel Bătrân (1406) în zona Tismanei (Giurescu 1976). Ulterior, apariția și dezvoltarea amenajării pădurilor la noi a fost strâns legată de cele petrecute în acest domeniu în Germania și Franța, începând cu sfârșitul secolului al XVIII-lea și până la începutul secolului al XX-lea.

În teritoriile românești aflate sub adminis-

\footnotetext{
${ }^{4}$ Silva, sau un discurs despre arbori și utilizarea lemnului în Domeniile Majestății Sale (engl.).

${ }^{5}$ Ordonanța lui Ludovic al XIV-lea pentru ape și păduri (fr.), cunoscută și sub denumirea de Ordonanța lui Colbert.

${ }^{6}$ Instrucțiuni privind valorificarea pădurilor sau pentru estimarea randamentului pădurilor (ger.).

${ }^{7}$,Locuri oprite sau rezervate, în care nimeni n-avea voie să intre spre a tăia lemne, a cosi fân, a paște vitele, a prinde pește sau a culege fructele pădurii, fără voia prealabilă a stăpânului" (Giurescu 1976).

${ }^{8}$ Drept dovadă este un act din 4 august 1400 de la Alexandru cel Bun, referitor la podul „lui Dragomir Brănișteriul” (Giurescu 1976).
} 
traţie şi ulterior sub dominaţie austro-ungară (Ardeal, Banat, Crișana, Maramureș, Bucovina), influența școlii germane de silvicultură s-a făcut simțită de timpuriu. Prin ,,Ordonanța forestieră din anul 1776" dată de împărăteasa Maria Tereza se reglementa paza și exploatarea pădurilor din Imperiul Habsburgic (Křepela 2005). În Transilvania apăruse în 1781 ,Orânduiala pădurilor Principatului Ardealului" (Rucăreanu și Carcea 1981), iar în Bucovina, în 1786, ,, Orândueala de pădure pentru Bucovina" dată de împăratul Iosif al II-lea. Acesta din urmă era considerat primul cod silvic tipărit în limba română și reglementa modul în care trebuie să se realizeze exploatarea în pădure astfel încât să se asigure perenitatea acesteia și făcea primele mențiuni referitoare la funcțiile de protecție ale pădurilor: ,pentru tâmplări de nenorociri, precum arsuri de foc și vărsături de apă [...] trebue să să cruțe o parte din aceste păduri [...]. Aciastă parte de pădure să să chiiame revărsată sau parte de pădure cruțată” (Kirileanu 1908). Dominația habsburgică a reprezentat astfel o punte rapidă de legătură către cele mai noi tehnici silvice ale vremii. Astfel, în anul 1817, se înființează la Sibiu prima Școală de Silvicultură de pe teritoriul României actuale, școală care mai funcționaîn 1860, fără a se cunoaște data încetării activității (Ivănescu 1972, Stănescu și Negruțiu 1983).

În Banat, prin Instrucțiunile forestiere din anul 1749, se indica exploatarea lemnului în parchete aşezate la rând, cu lăsarea de seminceri, iar prin , Regulamentul forestier grăniceresc" adoptat în anul 1788, se prevedea împărțirea fondului de producție în păduri oprite și păduri libere, cele din ultima categorie fiind împărțite în parchete anuale, menite să asigure continuitatea producției (Sabău 1946, citat de Dumitrașcu 2000). Pădurile grănicerești din Orlat și Năsăud, ca și celelalte păduri din Ba- nat și Ardeal, erau supuse acelorași dispoziții ale Regulamentului silvic al Împăratului Iosif al II-lea din 1781 (Giurescu 1976), care preciza utilizarea metodei parchetației și indica o serie de alte elemente de detaliu privind modul de gospodărire a pădurilor (Witting 1926). În anul 1807 s-a promulgat Codul Grăniceresc ce prevedea împărțirea pădurilor în parchete și păstrarea unui număr de 16-20 seminceri la jugărul cadastral, precum și efectuarea de plantații și semănături în locurile neregenerate. În anul 1826 au fost întocmite primele amenajamente, iar în amenajamentele realizate după 1846 (și revizuite la 5 sau 10 ani) era aplicată metoda cameralistă (Dumitrașcu 2000).

În contextul acestor teritorii, spre sfârșitul secolului XVIII au demarat primele lucrări de amenajare (în special sub forma ridicărilor în plan) în vederea exploatării sistematice și regulate a pădurilor, ce presupuneau împărțirea pădurii în parchete. Totuşi, abia pe la jumătatea secolului XIX au fost întocmite amenajamente mai detaliate ${ }^{9}$ dar, din păcate, lipsite de continuitate datorită lipsei personalului specializat și situației politice a vremii. În 1873 a fost înfiinţat de către administrația austro-ungară un serviciu special de amenajare a pădurilor aparținând statului și instituțiilor publice, cu rezultate remarcabile ilustrate prin emiterea de instrucțiuni de amenajare, respectiv prin întocmirea (până în 1914) de amenajamente definitive, sau revizuirea la 10 ani a celor existente, pentru mare parte a pădurilor din zona amintită (Gârbu 1934). Este vorba de amenajamente remarcabile prin precizia determinărilor și a organizării teritoriului, în special în cazul administrațiilor forestiere cu tradiție îndelungată precum Fondul Bisericesc din Bucovina, Comunitatea de avere grănicerească din Caransebeș, Comunitatea Fondului Grăniceresc din Năsăud și Societatea minieră din Banat (Rucăreanu și Carcea 1981).

\footnotetext{
9 În Banat, între 1860-1874, pădurile Societății Anonime Uzinele de Fier și Domeniile Reșița au fost dotate cu planuri topografice exacte și amenajamente care asigurau continuitatea tăierilor și raportul susținut, fiind aplicate la codru tăieri succesive, cu cicluri de producție de 80 de ani la fag și 120 de ani la gorun, iar la crâng ciclul de producție era de 40 de ani. Între 1889 și 1905 amenajamentele silvice au fost refăcute, pădurile fiind destinate producerii lemnului de mină (Sburlan 1935).
} 
Un exemplu în acest sens îl constituie pădurile Fondului Bisericesc Ortodox Român din Bucovina. Aici, amenajamentele silvice au fost întocmite mult mai devreme. Primul amenajament silvic a fost realizat pentru Ocolul silvic Iacobeni în anul 1786 de către Florian Müntzer, în vederea asigurării lemnului necesar pentru exploatările miniere din zonă. Au urmat în anii 1820-1821 alte ocoale silvice (OS), printre care și OS Pătrăuți. Din anul 1786, în aceste păduri a fost aplicată metoda parchetației până în 1867, când este înlocuită cu metoda cameralistă austriacă (Ichim 1988). Amenajamente mai detaliate au fost întocmite pentru cele 31 ocoale silvice ale Fondului Bisericesc după $1875^{10}$, între anii 1878 (începând cu OS Vatra Dornei) şi 1911 (la OS Vicovul de Sus şi OS Breaza), cu revizuire, de regulă, la 10 ani. În zona montană se practicau în special tăierile rase, cu mari dificultăţi ulterioare de regenerare artificială pe spații mari (Scharbert 2000). Aici, ca și în multe din pădurile din Transilvania, era adoptat un regim restrictiv pentru pădurile de protecție conform Legii Austriece din 1852 (Rucăreanu și Carcea 1981) și se puneau în aplicare metode de amenajare specificate prin instrucțiunile pentru amenajarea pădurilor de stat din Austria (Guttenberg 2001). Este de remarcat faptul că, la amenajarea pădurilor Fondului Bisericesc, în anul 1885, s-a renunțat la metoda la cameralistă şi s-a trecut la metoda arboretelor a lui Judeich (precursoarea metodei actuale a claselor de vârstă), îmbunătățită în 1920 şi aplicată cu continuitate în aceste păduri până în 1948 (Ichim 1988).

De asemenea, în Transilvania, gospodărirea pădurilor se realiza în baza unor planuri impuse de regimul ungar (Antonescu 1931), fiind orientată, mai ales după 1867, către interesele industriei, iar proprietarii de păduri erau preocupaţi doar de câștiguri imediate și cât mai mari, nu de sustenabilitate. Legea silvică ungară din 1879 a impus o serie de reguli în ceea ce privește utilizarea produselor pădurii, pro- ductivitatea pădurilor fiind determinată după încheierea procesului de întocmire a planurilor cadastrale în 1882 (Bedö 1896, citat de Rus 2014). Conform Codului silvic ungar din 1879, pădurile din Transilvania erau supuse regimului silvic şi trebuiau amenajate în funcție de starea lor, de nevoile proprietarului și de cerințele existente la nivel naţional, asigurându-se raportul susținut atât în ceea ce privește produsele lemnoase, cât și produsele accesorii (Danilescu 1894).

În Moldova, preocupări privind asigurarea continuității producției au existat încă din 1792, când domnitorul Alexandru Moruzi a oprit tăierea pădurilor fără ,nici o socoteală ". Apar apoi, atât în Moldova, cât și în Țara Românească, primele reguli referitoare la păduri, ce aveau în vedere paza acestora și care sunt cuprinse în ,,Regulamentul Organic din 1831 ". Aici se semnalează și necesitatea învățământului silvic (Giurescu 1976, Balabasciuc 2000).

Primele reglementări privind planificarea exploatărilor în Moldova sunt cuprinse în „Pravila pentru cruțarea pădurilor după moșiile mănăstirești și altele” a domnitorului moldovean Mihail Sturza, intrată în vigoare în 1843 (Radianu 1890, Rucăreanu 1967) și care conținea o serie de elemente de reglementare a procesului de producție, precum indicarea numărului de parchete anuale (40-80) în care să fie împărțită pădurea și orânduirea tăierilor. Legea a fost însă abrogată în 1851, urmând o perioadă de abuzuri asupra spațiilor silvestre (Balabasciuc 2000).

În 1793 în Muntenia și mult mai târziu (în 1870) în Dobrogea, apar reglementări similare (Giurescu 1976). Hrisovul lui Mihai Șuțu din 1785 împarte pădurile în: dumbrăvi - păzite de locuitori și din care aceștia pot lua lemne fără învoirea stăpânului; păduri de ghindă - din care se scot numai uscăturile; păduri neroditoare - din care lemnul poate fi exploatat fără restricții. În 1847 s-a adoptat și aici un hrisov

\footnotetext{
${ }^{10}$ Când a fost înființată Secția de amenajare a pădurilor din Bucovina, în cadrul căreia a activat cu dăruire inginerul Fr. Czech, din 1888 până la pensionare în 1943 (Ichim 1988).
} 
asemănător celui din Moldova (Radianu 1890), care se limita la a stabili doar numărul de rezerve la unitatea de suprafață. Primele lucrări practice cu caracter amenajistic aveau doar forma unor schițe întocmite între 1851 și 1853 cu sprijinul profesorilor și elevilor primei școli silvice înfiinţată în 1851 (Rucăreanu și Carcea 1981).

După 1831 au apărut primele încercări timide de înființare a unei administrații silvice cu sprijinul unor silvicultori străini. Abia în 1860, în Principatele Unite ale Moldovei și Țării Românești se constituie o Direcție a Pădurilor pe lângă Ministerul Cultelor, desființată însă în 1864. Ulterior, este reînființat Serviciul silvic, ce trece în 1871 la Ministerul de Finanțe, iar din 1884 la Ministerul de Agricultură, Industrie, Comerț şi Domenii. Întrucât exploatarea pădurilor a luat amploare, Serviciul silvic cunoaște o dezvoltare semnificativă. Prin decizia ministerială din 1896, teritoriul vechiului regat era împărțit în Inspecțiuni silvice, fiecare cuprinzând între 10 și 17 ocoale silvice, astfel încât în 1900 existau 96 ocoale silvice. Serviciul a funcționat până în 1910, când s-a înființat Casa Pădurilor, cu caracter autonom (Casa Autonomă a Pădurilor Statului - CAPS), cu 10 regiuni şi 175 ocoale silvice (Priboianu 1930).

Exceptând regulile și lucrările cu caracter primar amintite mai sus, în Principatele Unite ale Moldovei și Țării Românești și, ulterior, în România, înainte de anul 1880, nu existau alte reglementări ferme privind gospodărirea pădurilor statului, astfel încât aici ,,fiecare făcea cum îl tăia capul", utilizând lemnul pentru prelucrări industriale primitive, pentru foc, sau pădurea pentru pășunat (Teodorescu 1904). Pădurile erau exploatate după bunul plac al fi- ecăruia, fără reguli bine stabilite, urmărindu-se doar recoltarea exemplarelor valoroase, din specii de valoare cum sunt stejarul și bradul. Arboretele de fag din apropierea așezărilor erau defrișate pentru lemn de foc. Nici imediat după 1860 nu s-a simțit o îmbunătățire semnificativă: până în 1885, arboretele de rășinoase erau parcurse cu tăieri rase pe suprafețe mari, fiind lăsați 20-40 arbori seminceri (rezerve) la hectar, rău conformați, cu diametre de 15-30 $\mathrm{cm}$, iar pădurile rezultate erau fără valoare. Această practică a fost înlocuită cu grădinăritul concentrat, care presupunea recoltarea arborilor de rășinoase cu diametre mai mari de 50 cm (60-80 exemplare la hectar), rămânând pe picior doar exemplarele de fag și cele rău conformate și de mici dimensiuni de răşinoase (Davidescu 1898).

La sfârșitul secolului al XIX-lea, în România, au apărut preocupări pentru aplicarea tratamentului lămuririlor (tăierile succesive actuale), cunoscut și sub denumirea metoda lămuririlor și a însămânțării naturale ${ }^{11}$ (Țînțăreanu 1889, Popovici 1895, Davidescu 1898) - un sistem de rărire ${ }^{12}$ a arboretelor, menit să asigure regenerarea naturală. Tratamentul lămuririlor a derivat din grădinăritul concentrat, iar la primele aplicări presupunea recoltarea la tăierea de însămânțare a circa 30 de arbori la hectar, cu diametre mai mari de 50 cm, după care urmau tăierea secundară și cea definitivă, perioada de regenerare nedepășind 15 ani (Davidescu 1898). Astfel, au început să fie aplicate la noi tăierile succesive, ca mijloc de limitare a aplicării tăierilor rase (Negulescu et al 1973).

Primele diferențieri clare între modul de gospodărire a pădurilor de interes privat și cel de gospodărire a pădurilor de interes public (și

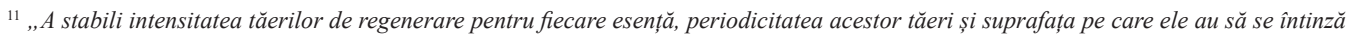
anual, constituie metoda lămuririlor și a reînsămânțărei naturale cu posibilitatea pe suprafață" (Popovici 1895). În 1895, profesorul N.G. Popovici propunea înlocuirea metodei afectațiilor pe volum (concepută de Hartig și aplicată greoi în unele păduri de la noi), cu metoda afectațiilor pe suprafață, preluată din silvicultura franceză.

${ }^{12}$ La sfârșitul secolului XIX, când foarte multe informații pătrundeau în România din silvicultura franceză, termenul lămurire era asociat răririi arboretelor, indiferent de stadiul de dezvoltare al acestora. La acea vreme, el era utilizat atât drept corespondent al curățirilor și, uneori, al răriturilor (Stătescu 1888a, 1888b, 1895), cât și pentru tăierile de regenerare ce presupuneau rărirea etapizată a arboretelor pentru promovarea regenerării naturale (Eleuterescu 1888, Apostolescu 1889, Davidescu 1894, Popovici 1895). Ulterior, termenul de lămurire a rămas în limbajul de specialitate din România doar drept corespondent al curățirilor.
} 
aflate în proprietate privată) sunt făcute prin Legea Silvică de la 1881 (primul cod silvic românesc). Aici se menționează că atunci când pădurile particulare sunt astfel situate (pe terenuri vulnerabile la eroziune, mișcătoare, la frontiera țării etc), încât existența și conservarea lor influențează interesul public, ele nu vor fi defrișate sau desființate. Mai mult decât atât, dacă astfel de păduri pot influența interesul public, nu doar ca urmare a existenței lor, ci și prin modul în care sunt exploatate sau îngrijite, modul de gospodărire va fi reglementat prin amenajamente silvice întocmite de specialiști (Popovici 1901).

Ca urmare a influenței școlii franceze de silvicultură de la Nancy, acest prim cod silvic românesc obliga la întocmirea amenajamentelor silvice pentru mare parte a pădurilor țării (Stinghe 1944) şi promova codrul regulat şi punerea în aplicare a metodei afectațiilor permanente, cu calculul posibilității pe suprafață (Rucăreanu 1967). În timp, prin documentarea silvicultorilor români ai acelor vremuri, au început să fie preluate (din silvicultura franceză și germană) și implementate, după caz, și alte metode de amenajare, precum: metoda parchetaţiei simple și proporționale, metode bazate pe afectații sau metode de normalizare a mărimii fondului de producție (Antonescu 1895).

Legea Silvică avea ca scop principal reducerea influenței distructive a omului, cu sau fără știinţă, asupra pădurilor. Obiectul acestei legi îl reprezentau pădurile statului, ale comunelor, stabilimentelor publice, comunităților, bisericilor, dar și ale particularilor. Prin această lege Administrația Domeniilor Statului avea obligația de a proceda la amenajarea pădurilor supuse regimului silvic în termen de cel mult 15 ani de la promulgarea legii, din pădurile respective urmând a se recolta lemn doar dacă sunt amenajate.

Amenajarea acestor păduri urma să fie realizată de Comisii compuse din cel puțin trei agenți silvici ai Statului. Agenții acestor comisii culegeau datele din teren în timpul verii, iar datele erau centralizate și prelucrate ulterior la sediul din București. După elaborare, amenajamentele silvice erau aprobate prin decret regal.

Lipsa personalului pentru efectuarea lucrărilor de amenajare (care presupuneau în primul rând ridicări în plan) și condiția impusă prin Legea silvică referitoare la numărul obligatoriu de agenți ai statului care compun o comisie de amenajare au constituit principalele cauze ale amenajării unor suprafețe nesemnificative de pădure în primii ani. Dintre pădurile de mare întindere ale Statului, până în 1892, s-au amenajat următoarele: Tarcău, Comana, Lucăcești, Paserea, Căscioarele, Cotmeana ș.a. (Anonymus 1898).

Lipsa unor regulamente de întocmire a amenajamentelor silvice, a personalului de specialitate și a experienței în domeniu (de cele mai multe ori, comisiile de amenajare erau formate din tineri absolvenți ai școlilor silvice din țară $^{13}$ ), lipsa instructorilor, a amenajamentelor anterioare și a cărților silvice în limba română au constituit principalele probleme ale începuturilor activităţii de amenajare a pădurilor în România (teritoriul Vechiului Regat).

Astfel, termenul de 15 ani impus prin Codul silvic nu a putut fi respectat, iar în multe situații calitatea amenajamentelor lăsa de dorit datorită grabei cu care erau întocmite: existau foarte multe cereri de întocmire a amenajamentelor din partea proprietarilor întrucât, în lipsa amenajamentelor, recoltarea de lemn era interzisă.

Cu titlu de exemplificare, în anul 1900, în Vechiul Regat al României, întreaga suprafață

\footnotetext{
${ }^{13}$ Conform Memoriului lui S.P. Radianu privind învățământul în agricultură și silvicultură, prima școală de agricultură din Principatele Române a fost înființată în Muntenia, în 1836, de către Alexandru Ghica Vodă, iar în Moldova a apărut odată cu înființarea catedrei de Economie rurală la Colegiul național, de către Gheorghe Asachi. Ulterior, au apărut și s-au desființat diferite școli și institute silvice precum: Școala de silvicultură din perioada 1851-1853 (numită și Comisia Forestieră a Valahiei) înființată în București de Știrbei Vodă cu profesori francezi; Școala de silvicultură cu durată de doi ani de la București (1860-1862), înființată de Mihail Rîmniceanu; Institutul de Agricultură și Silvicultură de la Pantelimon (1863-1869); Școala Centrală de Agricultură și Silvicultură de la Herăstrău (1869-1883), ce s-a transformat în 1883 în Școala specială de silvicultură, prima școală de silvicultură de nivel superior din România (Hepites 1887, Lazurian 1887, Stănescu și Negruțiu 1983).
} 
a pădurilor pentru care au fost întocmite amenajamente a fost de doar 19842 ha, fiind vorba în special de păduri particulare (79\%); pădurile amenajate aparținând statului, stabilimentelor publice sau comunelor ocupau suprafețe mult mai reduse (Păcescu 1901). În anul 1909, doar 10,4\% din pădurile statului erau amenajate; regimul codrului era majoritar $(70 \%)$, urmat de regimul crângului compus (28\%) și de crângul simplu (2\%), principalele tratamente adoptate în cazul regimului de codru fiind cele specifice codrului regulat cu regenerare sub masiv (54\%), urmate de codrul grădinărit (34\%) și tăierile rase (12\%) (Antonescu 1909).

Prin Codul silvic din 1910 se realizează o primă descriere a pădurilor de protecție, iar la articolul 2 se menționează clar că ,pădurile supuse regimului silvic nu se pot exploata decât în baza unui amenajament sau a unui regulament de exploatare aprobat prin decret regal" (Anonymus 1910). În funcție de forma de proprietate, aceste amenajamente erau realizate fie de către silvicultorii de stat, fie de proprii agenți silvici sau de către silvicultori recunoscuţi conform codului silvic. Amenajamentele sau regulamentele de exploatare întocmite de silvicultori recunoscuți erau verificate de Consiliul tehnic (consiliu consultativ care funcționa în cadrul Ministerului Agriculturii și al Domeniilor) și, după caz, pe teren, de către agenți silvici ai statului. Pădurile supuse regimului silvic cu o suprafață mai mică de 25 ha puteau fi exploatate doar în baza unui studiu sumar verificat de Consiliul tehnic și aprobat de ministru.

Până în anul 1918, literatura de specialitate aferentă amenajării pădurilor era deficitară, o primă lucrare în acest domeniu, scrisă în limba română, este reprezentată de Studiul asupra regulelor de exploatarea pădurilor, scris de profesorul de economie silvică Petre S. AntonescuRemuși în 1885 și tipărit la Tipografia Curții Regale, studiu care a servit drept suport de curs pentru elevii Şcolii Speciale de Silvicultură. Acest op, structurat în 6 părți și 25 de capitole și întins pe 178 de pagini, prezintă modul în care se realizează: descrierea unei păduri, 146 planurile generale de exploatare, trecerea de la codru neregulat la codru regulat, amenajarea în regim de crâng, respectiv conversiunea de la crâng la crâng compus și de la crâng compus la codru (Eleuterescu 1887).

\section{Perioada 1918-1947}

În timpul primului război mondial pădurile României Mari au fost puternic afectate ca urmare a extragerilor necontrolate de lemn, mult peste prevederile amenajamentelor. Din acest motiv, prin Decretul lege din 26 iunie 1919 și prin legile ulterioare, s-a impus anularea amenajamentelor anterioare și refacerea acestora, astfel încât să fie reflectată starea reală a pădurii, iar măsurile de gospodărire să corespundă noilor nevoi ale proprietarilor de păduri și ale economiei naţionale. Principalele dificultăți ale amenajării pădurilor imediat după război se datorau haosului economic și lipsei personalului silvic (Opran 1936). Cu toate acestea, prin legea din 1920 (de modificare a Codului silvic din 1910) se prevedea pedeapsa retragerii dreptului de a profesa pentru silvicultorii amenajişti care realizau descrieri parcelare inexacte, sau care nu puneau corect în aplicare legislația și metodele de amenajare (Comaniciu 1936).

În perioada României Mari (1918-1940), amenajarea pădurilor s-a cristalizat ca disciplină și domeniu de activitate însă, deși în plan teoretic au existat numeroase preocupări privind fundamentarea științifică a amenajamentului românesc, în anul 1937 încă se purtau discuții pe seama înființării comisiilor regionale de amenajare (Popescu-Zeletin 1937, Negulescu 1937, Moldovan 1937), iar în 1947 doar 39\% din pădurile României erau gospodărite pe bază de amenajament (Carcea et al 2000).

Conținutul amenajamentului a fost reglementat abia în 1923, când C.P. Georgescu a elaborat ,Instrucțiuni pentru intocmirea amenajamentelor" (Carcea și Dissescu 2007). Acestea, împreună cu cele emise de Comunitatea de avere din Caransebeş şi studiul profesorului Antonescu-Remuși, au fost singurele repere metodologice în amenajarea 
pădurilor până în 1939, când a apărut cursul profesorului Vintilă N. Stinghe.

După 1924 începea să prindă contur utilizarea fotogramelor și a stereorestituției în domeniul amenajării pădurilor, idee preluată din literatura germană (Antonescu 1924).

Sub raport teritorial-administrativ, prin decizie a Consiliului de Miniștri, în 1924 se descentralizează serviciile silvice, constituindu-se 13 Direcțiuni regionale, iar prin reorganizare se ajunge în 1930 la un număr de 11 Direcții (Arad, Bacău, București, Chișinău, Cluj, Constanța, Craiova, Iași, Orşova, Pitești, Sebeș) şi 205 Ocoale silvice (Priboianu 1930).

Datorită dificultăţilor întâmpinate în procesul de amenajare a pădurilor, mult timp s-a făcut distincţie între unităţile silvice cu rol administrativ (ocol silvic, brigadă, canton) și diviziunile forestiere utilizate în amenajarea pădurilor. Astfel, principala diviziune a fondului forestier utilizată în amenajarea pădurilor până în 1947 a fost secția, reprezentând o porțiune mai mare de pădure căreia i se aplică același regim. În cadrul secției se constituiau seriile. O serie era o parte din secție în care se aplica același tratament și se calcula o singură posibilitate de produse principale (Stinghe 1939).

În anul 1935, prin Legea 59 pentru pădurile necesare apărării naționale, se aduceau clarificări privind identificarea pădurilor de protecție și restricțiile impuse la gospodărirea acestora (Anonymus 1935).

Încă existau discrepanțe între modalitățile de planificare a exploatărilor, la revizuirea amenajamentelor fiind utilizate metode de amenajare moștenite de la austro-ungari în teritoriile ce s-au aflat sub dominație austro-ungară (Ichim 1996), iar în zona Vechiului Regat metode preluate din silvicultura franceză. Spre exemplu, în pădurile Fondului Bisericesc Ortodox Român din Bucovina erau încă aplicate instrucțiunile pentru amenajarea pădurilor din Austria, iar în unele păduri din Transilvania se continuau practicile anterioare ale regimului ungar (Antonescu 1931). La codru era aplicată majoritar metoda afectațiilor permanente (Stinghe 1936).
După 1930 pătrundea în literatura silvică din România Mare și metoda controlului, aplicabilă la codru grădinărit (Antonescu 1931), fiind întocmite primele amenajamente de grădinărit pe cupoane, ce au rămas lucrări de referință în domeniu: amenajamentul din 1930 al pădurii Piscul Câinelui din OS Sinaia (aici mai fusese aplicat după 1911 un aşa-numit grădinărit de protecție, ca și în unele păduri din Transilvania după 1900, care presupunea calculul posibilității pe suprafață și extragerea doar a arborilor căzuți, vicioși, deperisanți) și amenajamentul pădurii Slătioara din OS Stulpicani, întocmit în 1940 (Carcea et al 2013).

Tot după 1930 s-a realizat - mai ales în cazul pădurilor de codru cu stejar pedunculat sau gorun - trecerea de la calculul posibilităţii pe suprafață la posibilitatea pe volum, pentru a fi lăsată libertate silvicultorului la amplasarea tăierilor în timp și spațiu, astfel încât aceste specii să nu fie înlăturate din compozițiile viitoarelor arborete, cum se întâmpla anterior (Nedelcovici 1936, Stinghe 1936). În 1939, profesorul Stinghe descrie metoda claselor de vârstă (Stinghe 1939), iar în 1944 insistă pentru luarea acesteia în considerare drept alternativă la metodele bazate pe afectații (Stinghe 1944).

În perioada interbelică majoritar era regimul codrului, dar se adoptau și regimul crângului sau al crângului compus. Crângul compus și tăierile succesive practicate la codru regulat în virtutea metodei afectațiilor permanente cu calculul posibilității pe suprafață începeau să fie incriminate pentru degradarea multor păduri de fag sau a şleaurilor din zona deluroasă cu soluri grele (Ionescu 1936, Stinghe 1936, 1944). În ceea ce privește tratamentele, se aplicau tăierile succesive, progresive, cvasigrădinărite și rase în forma clasică sau cu unele adaptări locale. Aplicarea tăierilor grădinărite a fost limitată din 1935 doar la pădurile de protecție și la cele de raport (Costea 1962).

Tăierile progresive au început să fie puse în aplicare în mod experimental în 1920, fiind oficializate abia în anul 1938 (Negulescu et al 1973). Tăierile succesive erau aplicate în bră- 
dete pure, făgete pure, amestecuri de răşinoase cu fag, molidişuri care nu erau expuse doborâturilor de vânt (Paşcovici 1973), stejărete și șleauri. Aplicarea acestui tratament, conditionată de regulile stricte de planificare amenajistică, a condus la degradarea stejăretelor şi a şleaurilor, fiind de asemenea întâmpinate dificultăţi la regenerarea făgetelor datorită efectuării intervențiilor în afara anilor de fructificație (Negulescu et al 1973).

Până la al doilea război mondial, tăierile progresive erau aplicate în făgete sau molidișuri aflate în stațiuni optime de vegetație. Tăierile cvasigrădinărite cu perioadă de regenerare de 30-40 de ani erau adoptate în brădete, în amestecuri de rășinoase cu fag și în molidișuri cu structuri neregulate, aflate în staţiuni optime de vegetație. Tăierile rase se practicau doar în molidișuri (Pașcovici 1973), pe parchete mari și pe parchete mici.

Ca și în perioada primului război mondial, între 1940 şi 1947 lucrările de amenajare a pădurilor au continuat, însă au fost orientate în special spre revizuirea amenajamentelor existente și se desfăşurau cu mari dificultăți datorită lipsei resurselor financiare, materiale şi pericolelor asociate contextului istoric. În această perioadă apare (1941), sub formă de manuscris, „Proiectul de instrucțiuni pentru amenajarea pădurilor statului", elaborat timp de aproape un deceniu de I. Popescu-Zeletin, ce urma să constituie baza Instrucțiunilor de amenajare oficializate în anul 1948 (Carcea și Dissescu 2007).

\section{Perioada 1947-1989}

Legea 204 din 1947 pentru apărarea patrimoniului forestier a constituit un moment important pentru practica amenajistică din România, menționând la articolul 2 că ,,toate pădurile țării, indiferent de proprietar, vor fi amenajate in cel mult 4 ani de la data publicării legii de față” (Anonymus 1947). A urmat Legea naționalizării din 1948 prin care s-a făcut trecerea de la economia de tip capitalist la economia centralizată, iar toate resursele solului (inclu148 siv pădurile) și subsolului au fost etatizate (Anonymus 1948). Statul devenea marele proprietar al pădurilor, acestea urmând a fi amenajate și gospodărite unitar în întreaga țară. Termenul de 4 ani prevăzut în Legea 204 nu a putut fi respectat, însă până în 1956 toate pădurile țării erau amenajate (Leahu 2001).

Până în 1989 au fost emise mai multe ediții ale instrucțiunilor și normelor tehnice (1948, 1950, 1951, 1953, 1959, 1969, 1980 și 1986), iar cercetările din domeniu au condus la cristalizarea unui sistem naţional de amenajare a pădurilor.

În această perioadă, în silvicultura din România se făceau simțite influențele silviculturii sovietice (Predescu 1949). Astfel, au fost puse şi bazele sistemului românesc de tipologie forestieră (Pașcovschi și Leandru 1958, Purcelean și Pașcovschi 1968). Chiar de la primele instrucțiuni emise în această perioadă (Anonymus 1950) se renunţa la aplicarea crângului compus, iar pentru mare parte din pădurile gospodărite în regim de crâng urma un proces de conversiune la codru (Rucăreanu 1953). Posibilitatea urma să fie determinată în raport cu volumul la codru și în raport cu suprafața la crâng (Anonymus 1951). Ca metode de amenajare erau indicate prin instrucțiuni metoda claselor de vârstă pentru codru (cu luarea în considerare a urgențelor de regenerare), respectiv metoda parchetației simple sau proporționale în cazul crângului (Amzărescu 1953). Abia prin instrucțiunile din 1959 era descrisă și indicată pentru codrul grădinărit o variantă adaptată a metodei controlului (Anonymus 1959), numită metoda grădinăritului funcțional (Carcea et al 2000).

Instrucțiunile de amenajare din anul 1959 se remarcă și prin introducerea ridicărilor aerofotogrametrice ca metodă de actualizare a hărților amenajistice, a studiilor mai detaliate ale condițiilor de vegetație și a corelării măsurilor amenajistice cu condițiile respective (Dissescu 1966). Metoda aerofotogrametrică aplicată după 1959 la revizuirea amenajamentelor a permis realizarea unui sistem cartografic performant și unitar al fondului forestier național 
(Boș 2011).

Tot începând cu anul 1959, exploatabilitatea urma să fie stabilită diferențiat, în raport cu țelurile de gospodărire (fiind promovate în special exploatabilitatea tehnică, de protecție și de regenerare) (Anonymus 1959). Astfel, se realiza trecerea la exploatabilitatea tehnică, prin adaptarea la pădurile din România a metodei de determinare a exploatabilității tehnice preluată în 1958 din silvicultura rusă (Giurgiu 1988) și perfecționarea sa ulterioară (Giurgiu 1962, Giurgiu și Drăghiciu 2004).

Apărea conceptul de creștere indicatoare (Carcea 1959), care a condus la fundamentarea primei metode românești de amenajare a pădurilor aplicabilă pentru pădurile de codru regulat: metoda creșterii indicatoare (Carcea 1964, 1968, 1978). Aceasta de devenit, începând cu anul 1969, principala metodă de amenajare la codru regulat (Anonymus 1969), alături de care s-a aplicat cu continuitate metoda claselor de vârstă.

Perioada 1947-1989 este caracterizată de trecerea la amenajarea unitară a celei mai mari părți a pădurilor din România. Prin Legea 204/1947 pentru apărarea patrimoniului forestier, pădurile țării au fost grupate pe mari unități forestiere (MUF) ,, a căror întindere și structură trebuie să asigure, atât continuitatea procesului de producție, în vederea satisfacerii nevoilor de materie primă pentru industria forestieră, cât și un volum minim de produse care să asigure acoperirea cotelor de amortizare ale instalaților de transport și industrializare și rentabilitatea exploatărilor" (Milescu 1957).

Acestea erau subdivizate în unități de producție (serii), parcele și subparcele.

Marile unități forestiere erau de două tipuri: bazine (MUFB) în zonele de munte şi deal, respectiv grupe (MUFG) în zona de câmpie. Condițile de constituire a acestor mari unități forestiere au fost detaliate în instrucțiunile tehnice de amenajarea pădurilor elaborate în 1950. Spre exemplu (Anonymus 1950):

- suprafața minimă era de 10000 ha pentru MUFB și 3000 ha pentru MUFG;

- numărul de unități de producție trebuia să fie cuprins între 3 şi 30 pentru MUFB, respectiv între 5 şi 20 pentru MUFG;

- doar limite naturale pentru MUFB, limite naturale și artificiale pentru MUFG etc.

Totuşi, în multe situații, suprafețele MUF depășeau exagerat de mult pragurile minime, ajungând în zona de munte chiar la 100.000 ha, iar la câmpie la 40.000 ha (Rucăreanu 1955, citat de Leahu 2001).

Prin instrucțiunile pentru amenajarea pădurilor din anul 1959, se renunța la marile unități forestiere, iar ocolul silvic devenea unitatea teritorială de bază pentru amenajarea și administrarea pădurilor (Anonymus 1959). Tot în cadrul acestor instrucțiuni sunt prezentate și criteriile de constituire a ocoalelor silvice și modul în care acestea se împart în unităţi de producție, parcele și subparcele, dar se definește și subunitatea de producție sau protecție. În anul 1968 au fost înființate Inspectoratele Silvice Județene (ISJ) (Anonymus 1968). În 1989, în România existau 41 Inspectorate silvice cu 390 ocoale silvice ${ }^{14}$ (2213 unități de producție) ce administrau pădurile statului ${ }^{15}$.

În 1954, ca urmare a cercetărilor întreprinse de profesorul Ion Popescu-Zeletin, a fost oficializat, prin Hotărârea Consiliului de Miniștri nr. 114, primul sistem unitar de zonare funcțională a pădurilor din România (Giurgiu et al 1977). Ulterior, sistemul a fost îmbunătățit în raport cu evoluția cerințelor societăţii umane și cu rezultatele cercetărilor efectuate în domeniul silvic (ex. Dissescu 1967). Un pas important în gospodărirea pădurilor cu funcții speciale de protecție 1-a reprezentat realizarea corespondenței tratament-structură-funcție, pusă în aplicare odată cu introducerea conceptului de tip de categorie funcțională (Giurgiu

\footnotetext{
${ }^{14}$ La nivel național, suprafața medie administrată de un Ocol silvic era de circa 16250 ha, iar suprafața medie inclusă într-o unitate de producție de circa 2850 ha.

${ }^{15}$ Prin Legea nr. 119 din 11 iunie 1948 toate resursele solului (inclusiv pădurile) și ale subsolului și întreprinderile care nu se găseau în proprietatea statului erau naționalizate (Anonymus, 1948).
} 
et al 1977, Giurgiu 1988). În primii 30 de ani de la punerea în aplicare a sistemului românesc de zonare funcțională, suprafața pădurilor cu funcții speciale de protecție aproape s-a triplat, ajungând de la 12,7\% în 1955, la 36\% în 1984 (Drăgoi 2004).

Sistemul de zonare funcțională implementat din 1954 a constituit un instrument amenajistic decisiv pentru identificarea, delimitarea și excluderea de la orice intervenții a multor arborete care, după apariția Legii 9/1973 privind protecția mediului înconjurător, urmau să fie încadrate în rezervații științifice, rezervații ale naturii, sau alte categorii de rezervaţii, rezervații recunoscute și oficializate mult mai târziu ca arii protejate cu specific forestier, prin Legea protecției mediului din anul 1995 (Carcea 2003).

În perioada 1947-1989 apăreau primele preocupări privind prelucrarea automată a datelor de descriere a pădurii, în vederea unei mai facile analize a caracteristicilor fondului de producție (Dissescu și Cărtianu 1968, Vîrjoghe 1969, Seceleanu 1972, 1976, Neamțu 1972, Seceleanu et al 1975). Un prim pas 1-a reprezentat utilizarea mașinilor analitice de calcul cu cartele perforate (Dissescu 1965). În 1969, în cadrul Centrului de calcul al ICPIL, se prelucrează pentru prima dată pe un calculator electronic, evidențele amenajistice pentru șase ocoale silvice (Seceleanu 1976). Ulterior sunt realizate primele modele de simulare a evoluției structurii pădurii ca urmare a punerii în aplicare a planurilor amenajistice (Seceleanu 1978).

Prin Legea 2/1987 (Legea privind conservarea, protejarea și dezvoltarea pădurilor, exploatarea lor rațională economică și menținerea echilibrului ecologic) au fost promovate tăierile intensive și relativ intensive: grădinărite, cvasigrădinărite, progresive (Giurgiu 1989), limitându-se aplicarea tăierilor succesive.

După mărimea parchetului pot fi diferențiate două perioade de aplicare a tăierilor rase în România (Giurgiu et al 1977):

- până în 1985: parchetele mari erau cuprin150 se între 5 și 10 ha, iar parchetele mici aveau până în 5 ha;

- după 1985: parchete mari cuprinse între 3 și 5 ha, respectiv parchete mici sub 3 ha.

Existența unei strategii pe termen lung în domeniul silviculturii a permis o foarte bună corelare a planificării amenajistice cu serviciul de administrație silvică şi cu sectoarele de exploatare, prelucrare și industrializare a lemnului. Au apărut preocupările pentru valorificarea superioară a tuturor bunurilor și produselor oferite de păduri, inclusiv de obținere a sortimentelor superioare de lemn (ex. lemn pentru furnire, lemn de rezonanță și pentru claviatură), ceea ce presupunea și adaptarea modului de planificare amenajistică a producției respectivelor sortimente.

Pentru perioada 1947-1989 este definitorie amploarea pe care a cunoscut-o cercetarea în domeniul amenajării pădurilor în România, în special în ceea ce privește: calculul posibilității, definirea clară a bazelor de amenajare, obținerea automată a evidențelor amenajistice, inventarierea arboretelor, actualizarea tabelelor de producție, gospodărirea diferențiată a arboretelor cu funcții speciale de protecție, fundamentarea naturalistică și economică a amenajamentului, conservarea biodiversității, prognozarea evoluției fondului de producție și a posibilităţii etc. Este de remarcat apariţia unor lucrări de referință în domeniul amenajării pădurilor (ex. Rucăreanu 1962, 1967, Rucăreanu și Leahu 1982, Leahu 1984, Giurgiu 1988), ce au constituit repere esenţiale în fundamentarea strategiilor forestiere ale acelor ani și care au contribuit la dezvoltarea științei și practicii amenajării pădurilor din România.

\section{După 1989}

Amenajarea pădurilor în această perioadă este marcată de evenimentele care au avut loc în 1989 în România. A început o perioadă de tranziţie de la economia de comandă la economia de piață (Milescu 2002). Conceptul de proprietate a fost regândit conform principiilor democratice, fiind demarat procesul de recon- 
stituire a dreptului de proprietate către foștii proprietari sau moștenitorii acestora. Reconstituirea dreptului de proprietate asupra pădurilor s-a realizat etapizat, prin intermediul a trei legi emise în perioada 1991-2005. Astfel, s-a revenit la o structură complexă a formelor de proprietate, aspect care obliga la regândirea modului de întocmire a amenajamentelor silvice. Dacă în perioada anterioară putea fi considerată utilă întocmirea unui singur tip de amenajament, în această perioadă se impunea analizarea posibilității întocmirii de amenajamente distincte, în funcție de o serie de elemente precum: suprafața pădurii, etajul de vegetație, obiectivele proprietarului etc.

Sub raport teritorial-administrativ, cu unele modificări (Inspectoratele Silvice Județene erau denumite Direcții silvice), structurile din perioada anterioară s-au menținut până la apariția primelor ocoale silvice private. În 1999, drept consecință a modificării structurii proprietății asupra suprafețelor din fondul forestier, se reglementa modul de constituire, organizare și funcționare a ocoalelor silvice private (Anonymus 1999). După apariția ocoalelor silvice private, codul silvic din 2008, cu modificările și completările ulterioare, clasifica ocoalele silvice în două categorii (Anonymus 2008):

- ocoale silvice de stat, care administrează fondul forestier proprietate a statului, dar care pot administra, pe bază de contract, și păduri ale altor proprietari decât statul;

- ocoale silvice de regim, care sunt înființate de alți proprietari de pădure precum: unitățile administrativ-teritoriale (UAT), persoane fizice sau persoane juridice care au în proprietate fond forestier, sau asociații ale acestora.

În momentul actual fondul forestier al României este administrat prin intermediul a 474 ocoale silvice ${ }^{16}$, dintre care 327 ocoale silvice de $\operatorname{stat}^{17}$ şi 147 ocoale silvice de regim. Pentru toate pădurile României amenajarea se re- alizează pe unități de producție, dar în cazul pădurilor aflate în proprietatea statului sau în cazul marilor proprietăți forestiere există avantajul amenajării concomitente a tuturor unităților de producție dintr-un ocol silvic și al fundamentării pe spații mari a soluțiilor tehnice, cu luarea în considerare a stării generale a pădurii, la nivel de ocol silvic.

După 1989 pot fi identificate mai multe etape care au jalonat amenajarea pădurilor în această perioadă de tranziție. Până în 1998, practica amenajistică s-a desfăşurat după inerția imprimată de perioada comunistă, fără a fi aduse modificări majore sistemului de amenajare a pădurilor din România.

Conform Codului silvic din 1996, activitatea de amenajare a pădurilor putea fi realizată de unități specializate autorizate de autoritatea publică centrală care răspunde de silvicultură (Anonymus 1996). Astfel, în anul 2000, alături de ICAS, funcționau peste 20 de firme private autorizate (Carcea et al 2000).

Intre anii 1998 și 2005 au fost experimentate studiile sumare de amenajare a pădurilor pentru suprafețele mai mici de 30 de ha. Pentru suprafețele mai mari de 30 de hectare se aplicau reglementări similare celor anterioare. Avantajul întocmirii studiilor sumare consta în faptul că pădurile în cauză erau gospodărite conform unor planuri întocmite de specialiști. Dezavantajele se refereau în special la imposibilitatea respectării principiilor de bază ale unei gospodăriri durabile a resurselor forestiere. Astfel, în anul 2005 s-a renunțat pe cale legislativă la întocmirea lor (Anonymus 2005).

După 2005, alternativa oferită micilor proprietari de păduri a fost aceea de constituire a asociațiilor conform principiului teritorialității, iar suprafața cumulată a pădurilor aferente trebuia să depășească 100 de ha. Inițial, ideea de asociere $^{18}$ nu a fost acceptată de mulți dintre proprietari datorită percepției acestora asupra formelor asociative pe care le asimilau

\footnotetext{
${ }^{16} \mathrm{http}$ //apepaduri.gov.ro/paduri/

${ }^{17}$ Din subordinea Regiei Naționale a Pădurilor ROMSILVA, baze experimentale ale Institutului Național de Cercetare-Dezvoltare în Silvicultură „Marin Drăcea”, sau ocoale silvice din structura Regiei Autonome „Administrația Patrimoniului Protocolului de Stat”.
} 
celor existente înainte de 1989. Lipsa unei comunicări corespunzătoare din partea specialiştilor silvici, coroborată cu oprobiul proprietarilor de păduri față de opiniile acestora, a creat dezinteres față de activitatea de amenajare a pădurilor, astfel că suprafețe însemnate de păduri private au rămas neamenajate.

Conform Codului silvic din 2008, cu completările și modificările ulterioare, amenajamentele silvice se elaborează pe unități de producție și/sau de protecție (Anonymus 2008), $\mathrm{cu}$ respectarea normelor tehnice de amenajare a pădurilor. Este obligatorie întocmirea de amenajamente silvice doar pentru proprietăţile din fond forestier mai mari de 10 ha. Reglementarea procesului de producție pentru pădurile de pe proprietățile cu suprafețe mai mici de 100 ha, incluse în unităţi de producție/protecție constituite în teritoriul aceleiaşi comune, respectiv aceluiași oraș sau municipiu, se face la nivel de arboret, cu condiția asigurării continuităţii la acest nivel, aplicând tratamente adecvate. Se estimează că în momentul de față, circa $10 \%$ din fondul forestier al României nu este acoperit prin amenajamente silvice.

Ultimele norme tehnice în domeniu au fost elaborate în anul 2000, fără modificări semnificative față de ediția din 1986, ediție care a marcat de fapt orientarea clară a silviculturii către protecția mediului. Concret, pentru reglementarea producției sunt aplicate: i) în cazul codrului regulat - metoda creșterii indicatoare și metoda claselor de vârstă cu control prin metoda aproximațiilor succesive; ii) pentru codru grădinărit - metoda controlului (varianta românească), cu diferențiere în funcție de tipul de structură a arboretelor; iii) pentru codru cvasigrădinărit - metoda afectațiilor revocabile; iv) pentru crâng - metoda parchetaţiei simple, a parchetației proporționale sau a apro- ximațiilor succesive (Anonymus 1986, 2000).

Sistemul românesc de zonare funcțională a pădurilor a fost modificat în august 2018, incluzând o nouă subgrupă funcțională ${ }^{19}$ în grupa pădurilor cu funcții speciale de protecție, dar şi o serie de noi categorii funcționale în celelalte subgrupe (Anonymus 2018). Astfel, a venit în întâmpinarea unor noi cerințe de natură ecologică și socială, implementate mai ales în cazul parcurilor naționale, naturale, geoparcurilor, rezervațiilor biosferei, siturilor UNESCO sau al altor arii protejate din rețeaua ecologică Natura 2000, ori prin programele de certificare forestieră. Pădurile cu funcții speciale de protecție ocupau în 1994 circa 50\% din suprafața fondului forestier (Drăgoi 2004), estimându-se că în 2017 au ajuns la $57 \%$.

Datele culese din teren sunt prelucrate automat în integralitate în momentul de faţă, fiind dezvoltată, utilizată și periodic îmbunătățită aplicația informatică AS - Amenajamente silvice. Au apărut în această perioadă preocupările privind implementarea tehnicilor GIS la actualizarea materialelor cartografice atașate amenajamentelor silvice (Gancz 2003, 2005). Primele iniţiative au fost corelate cu implementarea procesului de certificare forestieră în România. De exemplu, în 2001 se transpuneau în format vectorial (GIS) hărțile amenajistice aferente Parcului Natural Vânători Neamț. Întocmirea harților amenajistice prin utilizarea unor aplicații informatice de tip GIS a avut un început mai timid însă, în momentul de față, reprezintă o practică curentă la elaborarea amenajamentelor silvice.

O altă particularitate a practicii amenajării pădurilor, mai ales după anul 2005, o reprezintă utilizarea dispozitivelor GPS pentru efectuarea ridicărilor în plan. Din păcate, randamentul sporit al obținerii coordonatelor din teren uti-

\footnotetext{
${ }^{18}$ Avantajele asocierii sunt evidente atât pentru proprietarul de pădure cât și pentru societate și pădure ca ecosistem: avantajele economice sunt resimțite imediat de proprietari întrucât se reduc semnificativ costurile fixe, pădurile sunt gospodărite pe suprafețe mari cu respectarea unor principii clar definite, iar capacitatea ecosistemelor forestiere de a oferi o gamă diversă de servicii societăţii umane este ameliorată semnificativ. Proprietarii de păduri trebuie să fie informați corect cu privire la avantajele gestionării resurselor forestiere pe spații mari, să cunoască alternativele pe care le au la dispoziție, astfel încât să fie conștienți că asocierea este cea mai bună soluție, iar decizia constituirii în asociații să le aparțină, nu să fie impusă de către autoritățile statului.

${ }^{19}$ Subgrupa 1.6 - păduri cu funcții speciale pentru conservarea și ocrotirea biodiversității.

${ }^{20} \mathrm{http}: / /$ apepaduri.gov.ro/wp-content/uploads/2014/07/Starea-p\%C4\%83durilor-\%C3\%AEn-anul-2017.pdf 
lizând, de cele mai multe ori, dispozitive GPS ieftine și cu precizie scăzută, a condus la o obținerea unor materiale cartografice imprecise, soldate uneori cu litigii sau cu situații confuze. Indiferent de metodele și de echipamentele utilizate, este indicată stabilirea unor precizii de determinare a coordonatelor de la care să nu fie admisă nicio abatere.

Activitatea amenajistică a devenit în ultimii ani tot mai complexă, întrucât au apărut noi cerințe care obligă la mai multă responsabilitate din partea amenajiştilor. Este vorba de identificarea, cu ocazia amenajării pădurilor, a arboretelor care ar putea fi încadrate în $\mathrm{Ca}$ talogul național al pădurilor virgine și cvasivirgine (Anonymus 2012) sau de coroborarea soluțiilor amenajistice cu măsurile de conservare prevăzute în planurile de management ale ariilor naturale protejate (Anonymus 2007).

În ceea ce privește bazele de amenajare stabilite după 1989, nu există modificări esențiale față de perioada anterioară, acestea fiind conforme normelor tehnice pentru amenajarea pădurilor din 1986 și 2000. Pentru majoritatea pădurilor din România este promovat prin Codul silvic (Anonymus 2008) și se adoptă regimul codrului. Deși regimul de codru este adoptat pentru circa $94,1 \%$ din suprafața pădurilor din România, doar 79,1\% din păduri ${ }^{21}$ sunt regenerate generativ (Duduman și Drăgoi 2019).

Totuşi, în ceea ce privește aplicarea tratamentelor, după anul 1989, neglijarea de către proprietarii și/sau administratorii de fond forestier a considerentelor de natură ecologică și socială a condus la reducerea semnificativă a sferei de aplicare a tăierilor intensive de tip grădinărit (Duduman 2011-a) și cvasigrădinărit, în favoarea tratamentelor cu tăieri progresive sau succesive.

Este de remarcat că, începând cu anul 1992, sistemul românesc de amenajare a pădurilor a început să fie aplicat și în Republica Moldova (Predoiu 1999), urmând unor diverse sisteme de amenajare aplicate de-a lungul timpului în acest teritoriu, în funcție de contextul istoric al ultimelor două secole (Galupa 2018).

Efervescența din perioada anterioară în ceea ce privește cercetarea în domeniul amenajării pădurilor s-a estompat. Studiile efectuate după 1989 au vizat aspecte referitoare la fundamentarea procesului decizional în amenajarea pădurilor (Dissescu 1990, Drăgoi 2002), calculul posibilității pe bază de cercetări operaţionale (Seceleanu 1998) sau perfecționarea metodei creșterii indicatoare (Leahu 2007, 2008), îmbunătățirea modului de reglementare a producției la codru grădinărit (Giurgiu 1993, Guiman 2007, Duduman 2009, Duduman 2011-b), actualizarea vârstelor exploatabilității tehnice (Cotos și Duduman 2017), utilizarea tehnicilor de simulare la întocmirea amenajamentelor (Nastasă 2000, Seceleanu 2003, Popa și Duduman 2016) ș.a. Dintre lucrările cu caracter monografic în domeniul amenajării pădurilor apărute în această perioadă se menționează cele publicate de Leahu (2001), Drăgoi (2004), Seceleanu (2012), sau Duduman și Drăgoi (2019).

\section{Concluzii și recomandări}

Studiul literaturii în domeniul amenajării pădurilor arată că una din principalele cauze ale degradării pădurilor din România - confirmată de la întocmirea primelor amenajamente silvice în pădurile românești și până în momentul de față - nu o reprezintă modul de întocmire a amenajamentelor silvice, ci punerea necorespunzătoare în aplicare a prevederilor amenajistice (ex. Opran 1936, Dissescu 1966, Carcea și Seceleanu 2016).

$\mathrm{Cu}$ toate acestea, există cazuri, destul de frecvente și astăzi, când amenajamentele sunt întocmite defectuos. Determinarea mai precisă a valorilor medii ce descriu din punct de vedere biometric elementele de arboret se impune ca măsură de îmbunătățire a activității amenajistice, alături de inventarierea atentă, prin mij-

${ }^{21} \mathrm{http} / / /$ roifn.ro/site/rezultate-ifn-2/ 
loace și procedee mai performante, a tuturor arboretelor incluse în planurile de recoltare a produselor principale. În felul acesta vor fi diminuate diferențele ${ }^{22}$ mari care au tot apărut, încă de la primele amenajări unitare în pădurile României actuale (Giurgiu 1970), între volumele înscrise în amenajamente şi volumele rezultate în urma punerii în valoare de către ocoalele silvice.

Amenajarea pădurilor din România este afectată şi de rezultatul concurenței dintre unitățile specializate autorizate pentru astfel de lucrări. Anii caracterizați printr-o cerere redusă pentru servicii de proiectare în acest domeniu își pun în mod evident amprenta asupra calității amenajamentelor silvice întrucât, pentru a contracta lucrările necesare supraviețuirii economice, multe din firmele respective preiau lucrări la prețuri foarte mici. Subfinanțarea acestor lucrări transformă amenajarea pădurilor într-un domeniu de activitate neatractiv pentru absolvenții bine pregătiţi ai facultăţilor de profil, cu efect nedorit mai ales asupra calității activității de amenajare.

În momentul de faţă se depun eforturi pentru definitivarea noilor norme tehnice pentru amenajarea pădurilor și a unei aplicații informatice mai performate pentru întocmirea amenajamentelor silvice. Este de dorit ca viitoarele norme tehnice să ia în considerare rezultatele cercetărilor efectuate până în prezent în domeniul amenajării pădurilor și în domeniile conexe acestei activități, astfel încât să răspundă noilor cerințe de ordin social și ecologic, referitoare în special la structura actuală a proprietăţii asupra suprafețelor din fondul forestier național, la importanța crescândă acordată implementării tehnicilor de modelare și de previzionare a evoluției stării pădurilor în diferite scenarii de schimbări climatice sau de management, la creșterea rezilienței pădurilor la acțiunea factorilor perturbatori prin promovarea unui tip de management adaptiv și a arboretelor de amestec cu structuri neregulate.
Alte provocări pentru amenajarea pădurilor din România și pentru îmbunătățirea acestei activități în viitor sunt: întocmirea mai riguroasă a amenajamentelor silvice; informatizarea tuturor etapelor întocmirii amenajamentelor silvice (inclusiv cea de teren), dar şi a monitorizării modului de implementare a prevederilor acestora; asigurarea unei cât mai bune colaborări între toți factorii implicați în întocmirea amenajamentelor; clarificarea limitelor fondului forestier acolo unde este cazul şi determinarea mult mai precisă a suprafețelor; pregătirea corespunzătoare a personalului, inclusiv în domeniul cartărilor staționale care, în momentul de față, este deficitar la nivel național; motivarea financiară corespunzătoare a personalului de specialitate, ținând cont de condițiile de muncă și de gradul de calificare ș.a.

Prin eforturi susținute s-a creat în România un sistem al amenajării pădurilor performant din punct de vedere tehnic, economic și ecologic, dar acesta presupune o permanentă îmbunătățire și, mai ales în viitorul apropiat, o orientare mai atentă către nevoile sociale.

\section{Mulțumiri}

Se aduc mulțumiri referenților articolului pentru sugestiile de îmbunătățire a manuscrisului.

\section{Bibliografie}

Amzărescu C., 1953. Propuneri pentru revizuirea și completarea instrucțiunilor de amenajare a pădurilor. Revista pădurilor, 68(3): 42-44.

Anonymus, 1898. Greutăţile întocmirei amenajamentelor în pădurile noastre. Revista pădurilor, Seria II, Anul II: 4-12.

Anonymus, 1910. Codul silvic din 1910. Monitorul Oficial, Partea I, nr. 8 din 09.04.1910.

Anonymus, 1935. Legea nr. 59 pentru pădurile necesare apărării naționale. Monitorul Oficial, Partea I, nr. 88 din 13 aprilie 1935.

\footnotetext{
${ }^{22}$ Acestea se datorează unor diferențe acceptabile între metodele utilizate, dar și întocmirii necorespunzătoare atât a amenajamentelor silvice, cât și a actelor de punere în valoare, cu diverse cauze (ex. Giurgiu 1970).
} 
Anonymus, 1947. Legea nr. 204 din 23 iunie 1947 pentru apărarea patrimoniului forestier. Ministerul Agriculturii și Domeniilor.

Anonymus, 1948. Legea nr. 119 din 11.06.1948 pentru naționalizarea întreprinderilor industriale, bancare, de asigurări, miniere și de transporturi. Monitorul Oficial, Partea I, nr. 133bis din 11.06.1948.

Anonymus, 1950. Instrucțiuni tehnice de amenajarea pădurilor. Ministerul Silviculturii și Industriei Lemnului, București, 112 p.

Anonymus, 1951. Instrucțiuni tehnice pentru amenajarea pădurilor - partea I. Ministerul Gospodăriei Silvice, Institutul de Proiectări Silvice, București, 103 p.

Anonymus, 1959. Instrucțiuni pentru amenajarea pădurilor din Republica Populară Română. Ministerul Agriculturii și Silviculturii, Editura Agro-Silvică de Stat, București, $145 \mathrm{p}$.

Anonymus, 1968. Hotărârea nr. 462/1968 privind reorganizarea și înființarea unor unități teritoriale sub îndrumarea și controlul Ministerului Economiei Forestiere. Buletinul Oficial nr. 32 din 13 martie 1968.

Anonymus, 1969. Instrucțiuni pentru amenajarea pădurilor din Republica Socialistă România. Ministerul Agriculturii și Silviculturii, Întreprinderea poligrafică „Tiparul”, București, 113 p.

Anonymus, 1986. Norme tehnice pentru amenajarea pădurilor. Ministerul Silviculturii, București, 197 p.

Anonymus, 1996. Legea nr. 26/1998: Codul silvic al României. Monitorul Oficial, Partea I, nr. 93 din 08.05.1996.

Anonymus, 1999. Hotărârea 997/1999 pentru aprobarea Regulamentului privind constituirea, organizarea și funcționarea structurilor silvice proprii, necesare pentru gospodărirea pădurilor proprietate publică aparținând unităților administrativ-teritoriale și a celor proprietate privată. Monitorul Oficial, Partea I, nr. 597/1999.

Anonymus, 2000. Norme tehnice pentru amenajarea pădurilor. Ministerul Apelor, Pădurilor și Protecției Mediului, București, 170 p.

Anonymus, 2005. Ordonanța de urgență 139 privind administrarea pădurilor din România. Monitorul Oficial, Partea I, nr. 939.

Anonymus, 2007. Ordonanța de urgență nr. 57/2007 privind regimul ariilor naturale protejate, conservarea habitatelor naturale, a florei și faunei sălbatice. Monitorul Oficial, Partea I nr. 442 din 29 iunie 2007.

Anonymus, 2008. Legea nr. 46/2008: Codul silvic al României. Monitorul Oficial, Partea I, nr. 238 din 27.03.2008.

Anonymus, 2012. Ordinul nr. 3397/2012 privind stabilirea criteriilor și indicatorilor de identificare a pădurilor virgine și cvasivirgine în România. Monitorul Oficial, Partea I, nr. 668 din 24.09.2012.

Anonymus, 2018. Normele tehnice privind elaborarea amenajamentelor silvice, modificarea prevederilor acestora și schimbarea categoriei de folosință a terenurilor din fondul forestier. Monitorul Oficial nr. $730 \mathrm{din}$ 23.08.2018, O.M. 766/2018, Anexa I.
Antonescu P., 1895. Diferite sisteme de amenajament și în special metoda austriacă. Revista pădurilor, 10(9): 275 284, 10(10): 312-322, 10(11): 343-347.

Antonescu P., 1909. Amenajarea pădurilor. Revista pădurilor, 24(3): 305-317.

Antonescu P., 1924. Amenajamente cu ajutorul fotografierei din aeroplan. Revista pădurilor, 36(11): 999-1002.

Antonescu P., 1931. Metodele de amenajament din Franța. Revista pădurilor, 43(1): 34-43.

Apostolescu E., 1889. Esploatarea pădurilor din regiunile muntose. Revista pădurilor, 6(6): 174-180.

Backmund F., 1935. Relativ la istoria amenajamentului în Bavaria. Revista pădurilor, 57(9-10): 685.

Balabasciuc C., 2000. Apărarea patrimoniului forestier: realitate sau ficțiune? Bucovina forestieră, 8(1): 43-47.

Boș N., 2011. Geomatica și realizarea bazei cartografice a fondului forestier din România. Revista pădurilor, 126(6): 27-36.

Buttinger S., 2013. Idee der Nachhaltigkeit. Damals, 45(4): 8.

Carcea F., 1959. Creșterea indicatoare, element de bază pentru controlul gospodăriei și pentru stabilirea posibilității în unitățile de producție de codru regulat. Revista pădurilor, 74(6): 25-27.

Carcea F., 1964. Metodă de amenajare pentru pădurile de codru regulat. CDF, București.

Carcea F., 1968. În legătură cu metoda de amenajare. Revista pădurilor, 83(12): 663-665.

Carcea F., 1978. Modalitate de calcul pentru stabilirea posibilității prin intermediul creșterii indicatoare. Revista pădurilor, 93(1): 663-665.

Carcea F., 2003. Amenajamentul silvic românesc și conservarea diversității biologice. Revista pădurilor, 118(6): 3-5.

Carcea F., Seceleanu I., Badea O., 2000. Amenajamentul și rolul lui în gestionarea durabilă a pădurilor. Revista pădurilor, 115(6): 1-7.

Carcea F., Dissescu R., 2007. Contribuțiile profesorului Ion Popescu-Zeletin în domeniul amenajării pădurilor. Revista pădurilor, 122(3): 47-51.

Carcea F., Leahu I., Guiman V., 2013. Realități și perspective în aplicarea codrului grădinărit în pădurile României. Revista pădurilor, 128(2): 11-17.

Carcea F., Seceleanu I., 2016. Contribuții privind fundamentarea unui sistem de control al elaborării și aplicării amenajamentului. Revista pădurilor, 131(1-2): 3-9.

Comaniciu I., 1936. Amenajarea pădurilor românești. Revista pădurilor, 48(4): 434-438.

Costea C., 1962. Codrul grădinărit. Editura Agro-silvică, Bucureşti, $146 \mathrm{p}$.

Cotos A., Duduman G., 2017. Vârste ale exploatabilității tehnice pentru principalele specii forestiere din România. Bucovina forestieră, 17(2): 115-129.

Danilescu N.R., 1894. Pădurile foștilor grănițeri români din Banat. Revista pădurilor, 9(9): 269-282.

Davidescu F., 1894. Dare de seamă asupra escursiunilor din Bucovina. Revista pădurilor, 9(2): 40-49.

Davidescu F., 1898. Pădurile răşinoase din țară. Revista 
pădurilor, 12(2-2): 81-88, 102-118.

Dissescu R., 1965. Exploatarea mecano-grafică a datelor amenajistice. Revista pădurilor, 80(9): 481-484.

Dissescu R., 1966. Probleme actuale ale amenajamentului românesc. Revista pădurilor, 81(4): 217-222.

Dissescu R., 1967. Amenajarea pădurilor de interes social, inclusiv a celor de interes turistic. Revista pădurilor, 82(10): 518-522.

Dissescu R., 1990. Abordarea bayesiană a deciziilor amenajistice. Revista pădurilor, 105(2): 62-65.

Dissescu R., Cărtianu E., 1968. Scheme-program pentru automatizarea calculelor în lucrările de amenajare. Revista pădurilor, 83(8): 414-420.

Doussot R., 1989. Cours sur 1'histoire des forêts, Document interne ENITEF, Nogent-sur-Vernisson, 6 p.

Drăgoi M., 2002. Deciziile amenajistice ca procese ierarhizate. Bucovina forestieră, 10(1-2): 3-12.

Drăgoi M., 2004. Amenajarea pădurilor. Editura Universităţii Suceava, Suceava, 258 p.

Duduman G., 2009. Fundamentarea ecologică a calculului posibilităţii în pădurile tratate în codru grădinărit. Editura Universităţii Suceava, Suceava, 300 p.

Duduman G., 2011-a. Silvicultura pădurilor neregulate în România: aplicarea codrului grădinărit. Revista pădurilor, București, 126(5): 21-36.

Duduman G., 2011-b. A forest management planning tool to create highly diverse uneven-aged stands. Forestry, 84(3): 301-314.

Duduman G., Drăgoi M., 2019. Amenajarea pădurilor Vol.1: Organizare spațio-temporală. Editura Universității Ștefan cel Mare Suceava, Suceava, X+209 p.

Dumitrașcu T., 2000. 260 de ani de silvicultură în Banat. Revista pădurilor, 115(1): 37-39.

Eleuterescu I.C., 1887. Bibliografie forestieră. Revista pădurilor, 2(2): 52-55.

Eleuterescu I.C., 1888. Priviri asupra exploatarei în crâng-compus. Revista pădurilor, 3(2): 54-61; 3(3): 8188; 3(4): 100-107.

Galupa D., 2018. Etape istorice în dezvoltarea sectorului forestier din Republica Moldova Revista pădurilor, 133(2): 48-57.

Gancz V., 2003. Cercetări privind aplicarea fotogrametriei, teledetecției și sistemelor informatice geografice în silvicultură - teză de doctorat. Universitatea Transilvania din Brașov, Brașov, 173p.

Gancz V., 2005. Utilizarea analizei GIS în silvicultură. Un studiu de caz. Revista pădurilor, 120(3): 40-44.

Gaudin S., 1996. Quelques éléments d'histoire forestière et généralités sur la forêt en France et dans le monde. BTSA Gestion Forestière, Module D32, Besançon 32 p.

Gârbu S., 1934. Monografia Fondului Bisericesc Ortodox-Român din Bucovina - manuscris. Cernăuți, 283 p.

Giurescu C., 1976. Istoria pădurii românești din cele mai vechi timpuri până astăzi - ediția a doua, revăzută și adăugită. Editura Ceres, București, 392 p.

Giurgiu V., 1962. Vârste optime de tăiere pentru pădurile din R.P. Română. Editura Agro-Silvică, București, $107 \mathrm{p}$.
Giurgiu V., 1970. Sistemul de inventariere a arboretelor la amenajarea și punerea în valoare a pădurilor corespunde actualelor cerințe? Revista pădurilor, 85(1): 44-45.

Giurgiu V., 1988. Amenajarea pădurilor cu funcţii multiple. Editura Ceres, Bucureşti, 290 p.

Giurgiu V., 1989. Tratamente intensive: realități și perspective. Revista pădurilor, București, 104(2): 58-63.

Giurgiu V., 1993. Stabilirea fondurilor de producție optime pentru pădurile amenajate în codru grădinărit. Revista pădurilor, 108(2): 51-51.

Giurgiu V., Pătrășcoiu N., Purcelean Ș., 1977. Gospodărirea polifuncțională a pădurilor și tratamentele. Revista pădurilor, București, 91(4): 190-196.

Giurgiu V., Drăghiciu D., 2004. Modele matematico-auxologice și tabele de producție pentru arborete. Editura Ceres, București, 607 p.

Guguianu I., 1908. Foloasele pădurilor pentru populațiune. Revista pădurilor, 22(3): 225-250, 290-308.

Guiman G., 2007. Cercetări asupra creșterii și calității arboretelor pluriene de fag gospodărite în codru grădinărit. Revista pădurilor, 122(6): 26-31.

Guttenberg A., 2001. Raport asupra excursiei Asociației Silvicultorilor din Austria în Bucovina si a 42-a adunare generală, ținută la Cernăuți (13-21 iunie 1897). Bucovina forestieră 9(1-2): 54-74.

Hartig G.L., 1795. Anweisung zur Taxation der Forste, oder zur Bestimmung des Holzer-Trags der Walder. Wiesbaden, $200 \mathrm{p}$.

Hepites Ş., 1887. Cauzele şi remediul înnecurilor şi depunerilor din bazinul Prahovei. Revista pădurilor, 1-2(4): 103-111.

Ichim R., 1988. Istoria pădurilor și silviculturii din Bucovina. Editura Ceres, București, 216 p.

Ichim R., 1996. Memorii Gheorghe Spătaru - cartograf. Bucovina forestieră, 4(1-2): 68-82.

Ionescu A.I., 1936. Tendințe noi în amenajament. Revista pădurilor, 48(4): 454-457.

Ivănescu D., 1972. Din istoria silviculturii românești. Editura Ceres, București, 335 p.

Kirileanu G.T., 1908. Cel mai vechiu cod silvic tipărit în limba românească: Orândueala de pădure pentru Bucovina. Revista pădurilor, Bucureşti, 7: 161-170, 9: 271279.

Křepela M., 2005. Čtvrt tisíciletí od vydání tereziánských lesních řádů (250 de ani de la emiterea Ordonanței Forestiere de către Maria Tereza). Zprávy Lesnického Výzkumu, 50(4): 264-270 (în cehă).

Lazurian A.L., 1887. Relativ la învățământul agricol și silvic. Revista pădurilor, 1-2(4): 114-119.

Leahu I., 1984. Metode și modele structural-funcționale în amenajarea pădurilor. Editura Ceres, București.

Leahu I., 2001. Amenajarea pădurilor. Editura Didactică și Pedagogică, București, 616 p.

Leahu I., 2007. Fundamente biometrice, metode și modele pluricriteriale privind stabilirea posibilității, conducerea și reglarea structurală și funcțională a pădurilor printr-un control periodic și sustenabil la producției forestiere (I). Revista pădurilor, 122(6): 13-19. 
Leahu I., 2008. Fundamente biometrice, metode și modele pluricriteriale privind stabilirea posibilității, conducerea și reglarea structurală și funcțională a pădurilor printr-un control periodic și sustenabil la producției forestiere (II). Revista pădurilor, 123(1): 11-20.

Milescu I., 1957. Propuneri privind organizarea teritoriului forestier (I). Revista pădurilor, 72(11): 720-723.

Milescu I., 2002. Economie forestieră. Grupul Editorial Crai Nou, Mușatinii, Suceava, 292 p.

Moldovan I., 1937. Comisiunile de amenajament și ridicări în plan. Revista pădurilor, 49(6): 684-690.

Nastasă L., 2000. Simularea așezării în spațiu a tăierilor la amenajarea pădurilor în codru regulat. Revista pădurilor, 115(6): 46-49.

Neamțu C., 1972. Automatizarea calculului volumului total și al celui pe sortimente în lucrările de amenajare a pădurilor. Revista pădurilor, 87(12): 604-607.

Nedelcovici A., 1936. Întâi amenajamentul. Revista pădurilor, 48(4): 447-450.

Negulescu V.P., 1937. Comisiunile de ridicări și amenajări. Revista pădurilor, 49(6): 678-684.

Negulescu E.G., Stănescu V., Florescu I.I., Tîrziu D., 1973. Silvicultura - fundamente teoretice și practice. Editura Ceres, București, 372 p.

Opran C., 1936. Mai multă atențiune la amenajarea pădurilor. Revista pădurilor, 48(4): 420-423.

Paşcovschi S., Leandru V., 1958. Tipuri de pădure din Republica Populară Română. Editura Agro-Silvică de Stat, București, 459 p.

Paşcovici N., 1973. Din istoricul silviculturii: tratamente folosite în trecut în pădurile din Nordul Moldovei. Revista pădurilor, 88(1): 33-35.

Păcescu M., 1901. Tablou de pădurile statului, stabilimentelor publice, bisericilor de mir, comunelor și particulare, amenajate în anul 1900, în conformitate cu art. 4 din Codul silvic. Revista pădurilor, Seria II, Anul V: 377.

Popa C., Duduman G., 2016. Aplicarea metodei claselor de vârstă la fonduri de producție puternic excedentare în arborete exploatabile: un studiu de caz. Bucovina forestieră 16(1): 23-41.

Popescu-Zeletin I., 1937. Comisiunile de amenajări. Revista pădurilor, 49(6): 690-697.

Popovici N.G, 1895. Codrul și tăerile pe suprafață. Revista pădurilor, 10(2): 54-59, 10(3): 78-87.

Popovici N.G., 1901. Libertatea de acțiune în silvicultură. Revista pădurilor, seria II, anul V: 6-12.

Predescu G., 1949. În preajma nouilor instrucțiuni de amenajare sovietice. Revista pădurilor, 64(4): 205-206.

Predoiu G., 1999. Sistemul românesc de amenajare a pădurilor, aplicat în Republica Moldova. Revista pădurilor, 114(5): 30-33.

Priboianu V., 1930. Organizarea administrativă a C.A.P.S. Revista pădurilor, 42(5): 414-430.

Purcelean Ș., Pașcovschi S, 1968. Cercetări tipologice de sinteză asupra tipurilor fundamentale de pădure. Ministerul Economiei Forestiere, Institutul de cercetări forestiere, Centrul de Documentare Tehnică pentru Economia Forestieră, 106 p.
Radianu S.P., 1890. Personalul pădurilor statului. Revista pădurilor, 5(7): 210-219, 5(8): 336-341.

Rucăreanu N., 1953. Despre amenajamentul de conversiune a crângurilor. Revista pădurilor, 68(1): 3-8.

Rucăreanu N., 1962. Amenajarea pădurilor - ediția I. Editura Agro-silvică, București, 368 p.

Rucăreanu N., 1967. Amenajarea pădurilor - ediția a II-a. Editura Agro-silvică, București, 453 p.

Rucăreanu N., Carcea F., 1981. Amenajarea pădurilor. În Chiriță C. (Ed.), Pădurile României - studiu monografic. Editura Academiei Republicii Socialiste România, București, 305-326.

Rucăreanu N., Leahu I., 1982. Amenajarea pădurilor. Editura Ceres, București, $438 \mathrm{p}$.

Rus D.-I., 2014. Wissenschaftliche Forschungen über die siebenbürgischen Wälder in der Neuzeit. Revista pădurilor, 129(1-2): 47-60.

Sburlan D.A., 1935. Transportul lemnelor de foc pe canale de apă, în pădurile Uzinelor Reșița. Revista pădurilor, 47(5): 335-358.

Scharbert F., 2000. Problema exploatărilor și a regenerărilor în pădurile Fondului Bisericesc Ortodox Român al Bucovinei. Bucovina forestieră, 8(2): 52-60.

Seceleanu I., 1972. Prelucrarea automată a datelor privind elaborarea evidenței structurii și mărimii fondului de producție în amenajament. Revista pădurilor, 87(12): 598-604.

Seceleanu I., 1976. Realizări și perspective în prelucrarea automată a informațiilor amenajistice. Revista pădurilor, 91(3): 161-162.

Seceleanu I., 1978. Utilizarea simulării în stabilirea influenței modului de reglementare a producției forestiere asupra structurii pădurii. Revista pădurilor, 93(1): 2728.

Seceleanu I., 1998. Cercetări privind aplicarea programării matematice și a modelelor de simulare în reglementarea procesului de producție în amenajament - teză de doctorat. Universitatea Transilvania din Braşov, Braşov.

Seceleanu I., 2003. Fundamentarea în amenajarea pădurilor a deciziilor de conducere a fondului de producție cu ajutorul modelelor de simulare. Silvologie IIIA, Editura Academiei Române, 75-115.

Seceleanu I., 2012. Amenajarea pădurilor - organizare și conducere structurală. Editura Ceres. București, 505 p.

Seceleanu I., Neamțu C., et al., 1975. Flux de programe privind redactarea automata a amenajamentului. Studii și cercetări ICAS, vol. XXXIII.

Stănescu V., Negruțiu F., 1983. La aniversarea centenarului învățământului silvic superior din România. Revista pădurilor, 98(4): 185-194.

Stătescu G., 1888a. Cercetări asupra tăerilor de lămuriri sau rărituri, în păduri. Revista pădurilor, 3(6): 166-168.

Stătescu G., 1888b. Cercetări asupra tăerilor de lămuriri. Revista pădurilor, 3(9): 267-270.

Stătescu G., 1895. Experiențe asupra efectelor tăerilor de rărituri (lămuriri). Revista pădurilor, 10(1): 9-11.

Stinghe V.N., 1936. Spre ameliorarea tehnicei amenajamentului. Revista pădurilor, 48(4): 474-480. 
Stinghe V.N., 1939. Amenajarea pădurilor. Editura Societății Progresul Silvic, București, 256 p.

Stinghe V.N., 1944. Amenajamentul nostru în viitor. Revista pădurilor, 56(3-6): 132-133.

Teodorescu I., 1904. Câteva observaţiuni asupra legislaţiei noastre forestiere. Revista pădurilor, 18(8): 195-201.

Țînțăreanu A.T., 1889. Exploatarea pădurilor de munte. Revista pădurilor, 4(1): 5-23.

Vîrjoghe S., 1969. Calculatorul electronic Olivetti-Programma 101 folosit pentru calcule în amenajament. Revista pădurilor, 84(9): 457-460.

Westoby J., 1989. Introduction to world forestry: people and their trees. Oxford: Blackwell, $228 \mathrm{p}$.

Williams M., 2006. Deforesting the Earth: From Prehistory to Global Crisis, an Abridgment. University of Chicago Press, Chicago, XVIII+543 p.
Witting O., 1926. Câte-va date din istoria pădurilor comunale din județul Brașov. Revista pădurilor, 38(5): 299304.

\section{Pagini web}

http://www.fao.org/3/x5347e/x5347e04.htm\#TopOfPage, accesat Decembrie 2019.

http://roifn.ro/site/rezultate-ifn-2/, accesat Octombrie 2019.

http://apepaduri.gov.ro/paduri/, accesat Decembrie 2019. http://apepaduri.gov.ro/wp-content/uploads/2014/07/Starea-p\%C4\%83durilor-\%C3\%AEn-anul-2017.pdf, accesat Decembrie 2019. 